\title{
Viral Prevalence in Wild Serval Population is Driven by Season and Sex
}

\author{
Daan J. E. Loock, ${ }^{1}$ Emilio Rendón-Franco, ${ }^{2}$ Samual T. Williams, ${ }^{3,4,5}$ Johan van Niekerk, ${ }^{1}$ \\ and Lourens H. Swanepoel ${ }^{3}$ \\ ${ }^{1}$ Centre for Sustainable Agriculture, Faculty of Natural and Agricultural Sciences, University of the Free State, 205 Nelson Mandela Drive, Park West, \\ Bloemfontein 930, South Africa \\ ${ }^{2}$ Departamento de Producción Agrícola y Animal, UAM-Unidad Xochimilco, Calzada del Hueso, Coyoacán, Ciudad de México 04960, México \\ ${ }^{3}$ Department of Zoology, School of Mathematical and Natural Sciences, University of Venda, Private Bag X5050, Thohoyandou 0950, South Africa \\ ${ }^{4}$ Department of Anthropology, Durham University, Durham DH1 3LE, UK \\ ${ }^{5}$ Institute for Globally Distributed Open Research and Education (IGDORE), Göteborg, Sweden
}

\begin{abstract}
One of the key factors influencing the population dynamics of threatened species such as felids is disease, but long-term studies of the factors influencing seroprevalence of wild felids are extremely rare, hindering conservation efforts. We set out to determine seroprevalence of six viral diseases (feline panleukopenia virus, feline leukemia virus, feline coronavirus, feline calicivirus, feline herpes virus, and feline immunodeficiency virus) among a population of serval (Leptailurus serval) with an extremely high density in South Africa. We captured 55 individuals over four years and screened blood samples for antibodies to each virus. We found that seroprevalence were high (ranging from $30.0 \%$ positive for a single virus to $1.8 \%$ positive for up to five viruses) and that seroprevalence was influenced by season and sex, but not body condition. We suggest further monitoring of this population and recommend that long-term studies are conducted for serval and other felids to determine whether these trends are representative on a broader scale.
\end{abstract}

Keywords: Carnivore, Felidae, Wildlife disease

\section{INTRODUCTION}

In wildlife populations, disease has many detrimental effects. For example, among feline viruses, feline coronavirus can cause chronic diarrhea associated with inappetence, weight loss, and severe immunosuppression (Kennedy et al. 2003). This causes increased mortality rates and reduced

Supplementary Information: The online version contains supplementary material available at https://doi.org/10.1007/s10393-021-01533-z.

Published online: May 31, 2021

Correspondence to: Daan J. E. Loock, e-mail: daanje.1@mweb.co.za recruitment (e.g., higher abortion rates and deaths by secondary causes) (Kennedy et al. 2003; Bradley and Altizer 2007), which may lead to local population extinction (Franklin et al. 2008). Feline leukemia virus for example has been identified as the most prominent cause of mortality in an Iberian lynx (Lynx pardinus) population with different agents (such as canine parvovirus, Toxoplasma gondii) (Meli et al. 2010) that have the potential to provoke deaths in this carnivore population (Bradley and Altizer 2007). This may have a similar devastating effect on other carnivore populations that occur at a high density. Despite the importance of disease and the effects on wildlife, our 
understanding of mesocarnivore epidemiology is still hampered by a dearth of baseline data (Franklin et al. 2008; Munson et al. 2010). Natural hosts for diseases are poorly described for wildlife populations in general, and almost nothing is known in some geographical areas (Ostrowski et al. 2003). This is even true for relatively well-studied taxa such as felids, where several viral diseases are particularly important as they are often the cause of fatalities. The understanding of wild felid viral pathogens is therefore important to mesocarnivore conservation.

Several factors, both environmental and biological, are believed to affect disease prevalence and susceptibility. For example, one factor strongly associated with disease prevalence in mammals is their body condition index (BCI) (Renwick et al. 2007). The body condition index is a standardized noninvasive tool (Green 2001) to evaluate the fitness of an individual animal based on physical characteristics. Body condition index can be an indication of general fitness and fat deposits based on phenotypic observations (Schulte-Hostedde et al. 2005). BCI is therefore strongly related to reproduction and survival potential (Schulte-Hostedde et al. 2005). Furthermore, malnutrition, lameness, and respiratory infections all seem to directly affect body condition (Jakob et al. 1996; Renwick et al. 2007). BCI tends to be lower in infected individuals than in uninfected individuals (Fromont et al. 2000). A closely related factor, and often associated with BCI, affecting disease prevalence is season. For example, harsh weather conditions and temperature fluctuations will often result in poor nutrition (Smith et al. 2009) and low investment in reproduction, and weaken immune system (Dowell 2001; Pedersen 2009). These effects may cause undesirable consequences for wild felid species, so it is particularly important to protect native carnivores from these unpredictable outcomes (Ferreira and Funston 2010).

In this study, we focus on the viral prevalence of a population of serval (Leptailurus serval) inhabiting the natural areas surrounding an industrial petrochemical plant located in Secunda, Mpumalanga Province, South Africa (central coordinates $26^{\circ} 31^{\prime} 45.62^{\prime \prime} \mathrm{S}, 29^{\circ} 10^{\prime} 31.55^{\prime \prime} \mathrm{E}$ ) (Loock et al. 2018). This population is a unique model system for disease ecology for several reasons. Firstly, the area has the highest serval density recorded (Loock et al. 2018) and such high densities can increase transmission rate and susceptibility to disease infection (Lindenfors et al. 2007). Secondly, even though the serval population seems to be stable through sampling periods, there are indications of population cycles through wet and dry seasons (Loock et al. 2018), which suggests population changes may be due to sources of mortality such as disease. Combined with high densities, the wet and dry seasons can add additional pressure, which could affect disease prevalence (Naidenko et al. 2014). Thirdly, the study area is embedded within a human-dominated matrix with varying levels of human activity, industrial contaminants, domestic animals (livestock and pets), and local native fauna (Fig. 1). We aim to provide the first long-term prevalence data for a range of viral diseases in this free-ranging serval population. Secondly, we evaluate body condition index (BCI) in combination with a suite of biological and environmental factors to investigate the factors associated with viral prevalence. We hypothesized that BCI will be affected by sex (higher in males compared to females) and season (lower in dry season). Furthermore, we hypothesized that feline virus prevalence will be affected by BCI (higher risk for low BCI scores), season (higher risk in wet season), sex (higher in females), and age (higher risk in older animals).

\section{Methods}

\section{Study Site}

Secunda Synfuels Operations Plant (a division of Sasol South Africa) is an industrial petrochemical plant located in Secunda, Mpumalanga Province, South Africa, which employs an estimated 12,500 permanent employees. The western boundary of the site is neighbored by an informal settlement (Embalenhle), with an estimated human population of approximately 147,122 (Matooane et al. 2011). The northern edge of the complex is adjacent to an industrial development, golf courses, and the Secunda town, with an estimated human density of 41,000 (Matooane et al. 2011).

The site has a rich diversity of mammal species, including 11 carnivore species; African clawless otter (Aonyx capensis), black backed jackal (Canis mesomelas), Cape fox (Vulpes chama), large grey mongoose (Herpestes ichneumon), serval, slender mongoose (Galerella sanguinea), small spotted genet (Genetta genetta), suricate (Suricata suricatta), water mongoose (Atilax paludinosus), whitetailed mongoose (Ichneumia albicauda), and yellow mongoose (Cynictis penicillata) (Emslie 2018). 


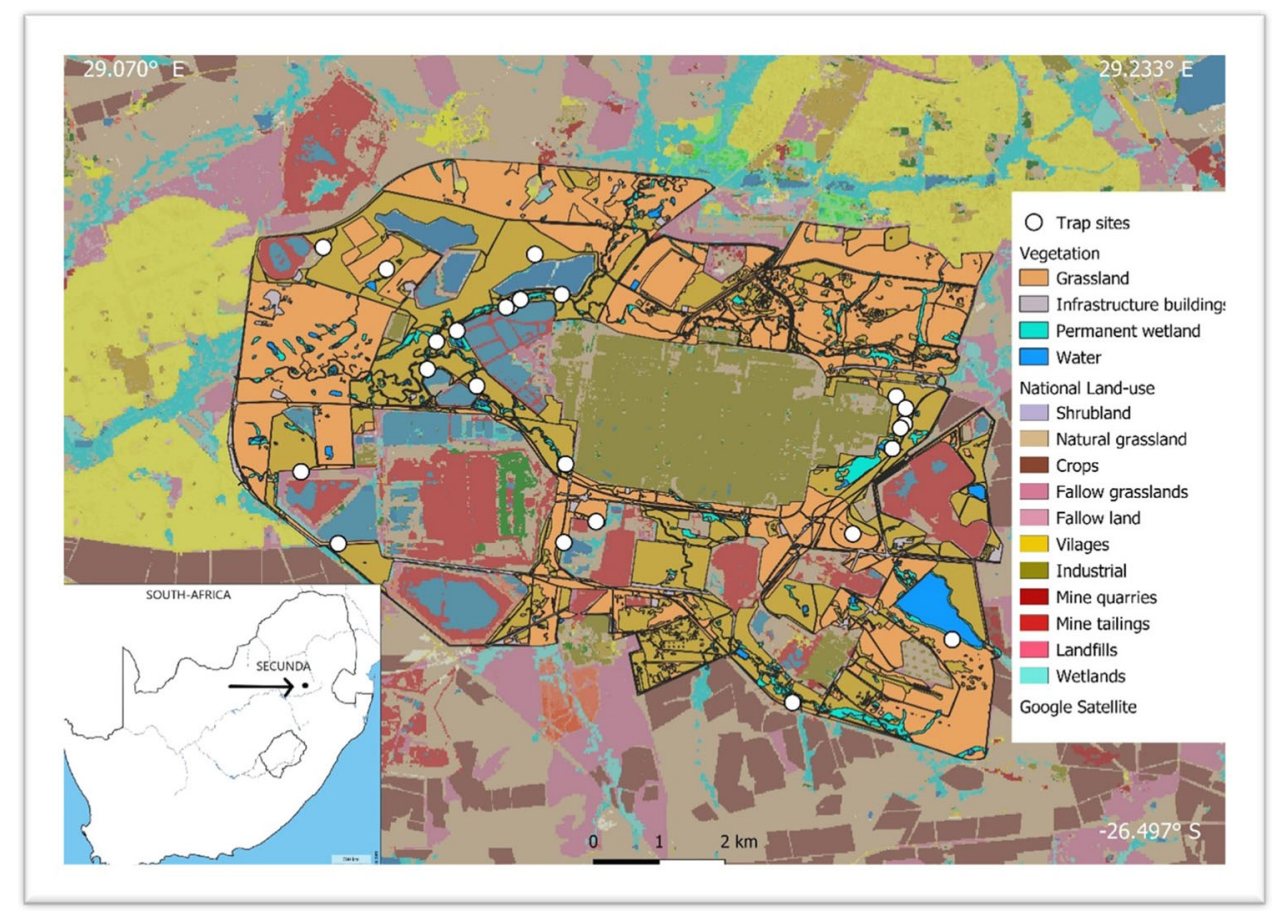

Figure 1. The study site in context of the larger surrounding landscape, highlighting human activities and land uses including settlements, agriculture, industry, and natural areas.

\section{Live Trapping}

Live trapping of serval formed part of a research project investigating wild serval spatial and disease ecology. We trapped serval during five sessions for a total of 477 trap nights between 2015 and 2018, using steel trap cages measuring $200 \mathrm{~cm} \times 80 \mathrm{~cm} \times 80 \mathrm{~cm}$. We deployed cages at 41 different locations throughout the study site, which were selected based on information gained from camera trapping.

Captured servals were immobilized by a qualified veterinarian, using standard immobilization protocols for felids (Morris 2001). Blood samples were collected during the deployment of GPS collars, microchips, and the collection of body measurements including age, sex, and weight. Servals were classified as adults (body mass $10.0 \mathrm{~kg}$ or more), subadults: $(7.0 \mathrm{~kg}$ to $9.9 \mathrm{~kg}$ ), and juveniles: $(<7.0 \mathrm{~kg}$ ) (Fromont et al. 2000). Samples from all 55 animals were screened for viral antigen or antibodies.

\section{Blood Sample Collection and Analysis}

Blood samples were collected from the jugular veins using BD Vacutainer ${ }^{\circledR}$ tubes containing a clot activator and were centrifuged for ten minutes at 1500 revolutions per minute, after standing for approximately an hour after collection.
All serum samples were submitted to the laboratory for analysis within $12 \mathrm{~h}$ after collection. IDEXX Laboratories located in Johannesburg, South Africa (SANAS accredited veterinary laboratory number V0040), were contracted to analyze the blood samples throughout the study.

\section{Viral Screening}

Samples were screened for antibodies to the following viral pathogens: feline calicivirus (FCV), feline coronavirus (FCoV), feline herpesvirus (FHV), feline panleukopenia virus (FPLV), feline immunodeficiency virus (FIV), and for viral proteins for feline leukemia virus (FeLV). The indirect immunofluorescent antibody assay (IFA, IDEXX®) was used for FCV, FCoV, FHV and FPLV, and enzyme-linked immunosorbent assay (ELISA, IDEXX ${ }^{\circledR}$ ) was used for FIV and FeLV. For FIV, ELISA IDEXX ${ }^{\circledR}$, even when there are different species-specific FIV, the test has showed concordance with some FIV from wildcats with just slightly less sensitivity (Brown et al. 2010).

\section{Calculation of Body Condition Index}

We calculated serval body condition index (BCI), a proxy for body fat (Labocha et al. 2014), using the log body mass/ log body length ratio. Body mass was the total body weight 
$(\mathrm{kg})$ of captured animals, and body length was measured from the tip of the nose to the base of the tail $(\mathrm{cm})$. Although the use of ratio indices has limitations when comparing between species, they are adequate for intraspecific comparisons (Jakob et al. 1996; Fromont et al. 2000).

\section{Data Analysis}

Our modeling framework was underpinned by an information theoretic approach, which allowed us to test several biologically plausible hypotheses, using multiple linear regression (Burnham and Anderson 2002). To investigate the variation in $\mathrm{BCI}$, we fitted linear models to test several hypotheses. First, we hypothesized that sex influences BCI since male animals generally have higher BCI compared to females (Windberg et al. 1991; Pulliainen et al. 1995). Further, we let BCI vary by season since seasonal effects such as ambient conditions and prey availability may influence BCI (Windberg et al. 1991; Pulliainen et al. 1995). We also fitted models including both season and sex, as well as a season and sex interaction models, since females lactating in dry season will incur higher metabolic costs (Windberg et al. 1991).

We further hypothesized that BCI, season, sex, and age of serval could affect the prevalence of the diseases tested. We used generalized linear models with a log link function and binomial distribution to estimate the effect of BCI, sex, age, season, sex + age, and sex + season on the prevalence (Luo et al. 2014). We restricted the model fitting to these variable combinations to avoid over parametrization of models. Relative risk can be seen as a ratio of success probability in a specific group compared to another (Luo et al. 2014). We fitted a log-binomial model for each disease separately (FCV, FHV, FCoV, FPLV, and FIV) and ranked models according to Akaike's information criterion corrected for small sample sizes (Akaike 1974; Luo et al. 2014). Since we had a small number of animals recaptured on successive occasions, we removed re-captured animals from analysis to avoid pseudo-replication. Model fit was evaluated for the most parsimonious model using the Hosmer-Lemeshow goodness of fit test and visual inspection of the residual plots. Log-binomial regression models were fitted by maximizing the likelihood based on the expectation-maximization (EM) algorithm, which seems to improve likelihood estimation, using the logbin package (Donoghoe and Marschner 2018) in R version 3.6.1 (Pinheiro et al. 2019). Models within a $\triangle$ AICc of 2 were con- sidered to have equal support. We further assessed variable importance using two methods. First, variables falling within the $\triangle \mathrm{AICc}$ of 2 of the top models were further assessed by sequential likelihood ratio tests. We dropped variables if the likelihood ratio suggested that variable reduced model fit. Secondly, we assessed the overlap in confidence intervals for predicted variables and dropped variables if significant overlap in confidence intervals occurred (Cumming 2009).

We estimated viral prevalence as the proportion of animals that tested positive for antibodies to pathogens (except FeLV, with all servals testing negative). Confidence intervals for pathogen prevalence were estimated using the Wald interval (normal approximation interval) using the prevalence R package (Devleesschauwer et al. 2014). All figures were prepared using ggplot2 (Wickham 2009).

\section{RESULTS}

During the study period, 55 animals were captured (including recaptures), which consisted of 34 adults (21 males and 13 females), 20 subadults ( 5 males and 15 females), and one juvenile (a female). Most animals were trapped in the wet season (47 animals), with only 8 individuals captured in the dry season (Fig. 1S). From these captures, several animals were trapped on more than one occasion. Three males were captured twice, two females were also captured twice, and one male was captured on three occasions.

\section{Body Condition Index}

Due to uncertainty in age classification of subadults, we restricted BCI analysis to adult serval. We found support that the body condition index (BCI) was affected by sex of serval (Fig. 2S; combined model weight of $<2 \Delta$ AICc $=$ 0.78 ), with little support for seasons (Fig. 2S), or the season ${ }^{*}$ sex interaction (Fig. 2S). Male serval had a higher BCI $($ mean $=0.57)$ compared to female serval $($ mean $=$ 0.54; Fig. 2S).

\section{Viral Screening}

Of the 55 individual servals we screened for viral diseases, antibodies were detected for FCV, FCoV, FHV, FPLV, and FIV (Fig. 2). All samples screened against FeLV resulted as FeLV-antigen negative. Prevalence for diseases screened varied over the sampling period (Fig. 2). Two viral diseases 


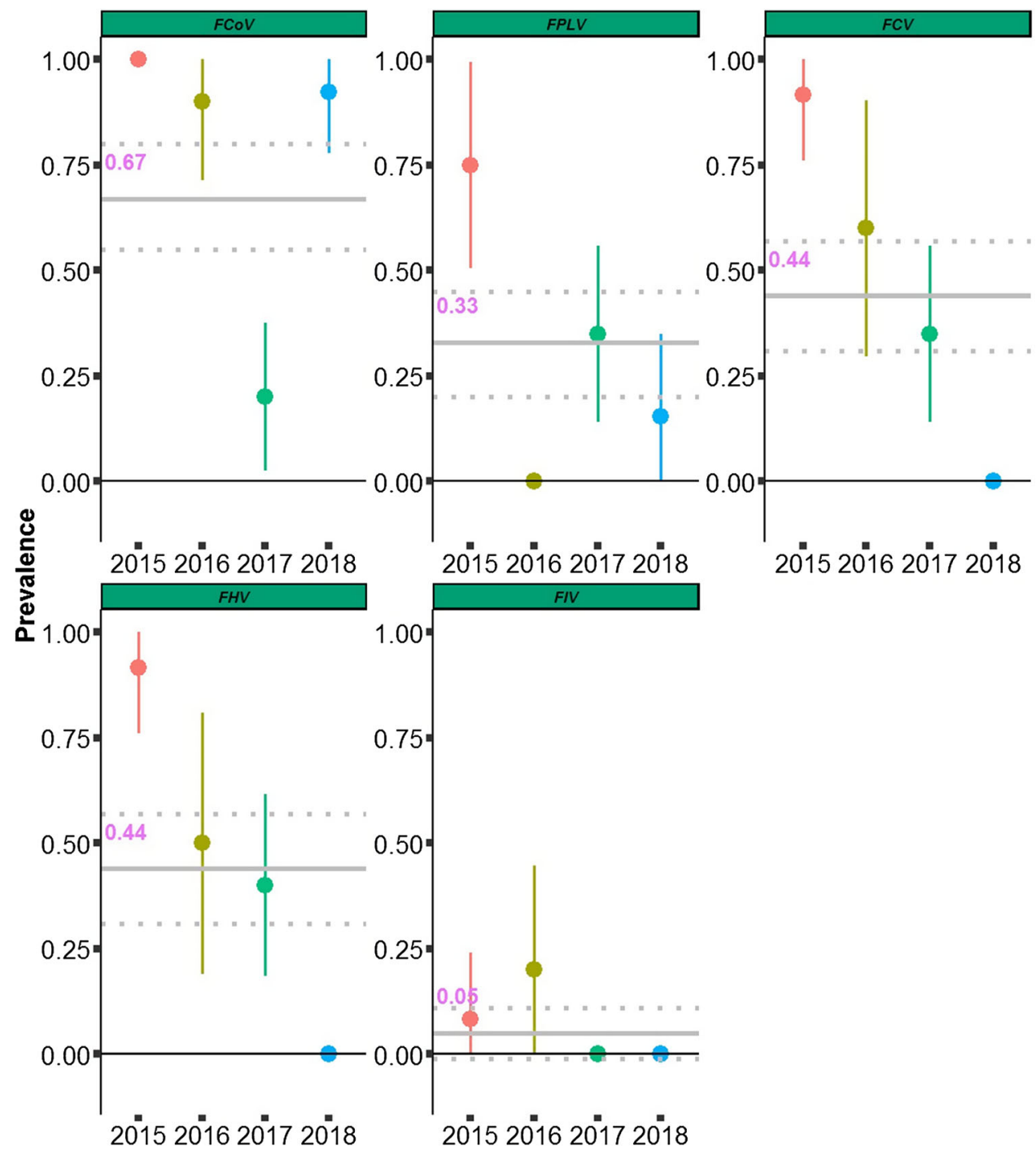

Figure 2. Annual variation in viral prevalence for five viruses tested (FCoV, FPLV, FCV, FHV, and FIV). Solid grey horizontal line represents the mean prevalence over study period and dotted lines $95 \%$ confidence interval; vertical lines represent $95 \%$ confidence interval for yearly prevalence rates.

(FCoV and FPVL) showed declines and increases over study period (Fig. 2), while FCV and FHV showed sharp decline since first sampling (Fig. 2). Mean prevalence over the 4-year sampling period was highest for FCoV (mean $=67 \% ; 95 \%$ CI: $55-80 \%)$, followed by FCV and FHV (mean $=44 \%, 95 \%$ CI: $31-57 \%$, respectively), and FPLV (mean $=33 \%$; 95\% CI: $20-45 \%$ ) (Fig. 2). FIV had the lowest prevalence of the 4-year sampling period mean $=5 \%$ (95\% CI: $0-11 \%)$ (Fig. 2). Ten animals $(18 \%$ of those screened) had no antibodies for any of the viruses tested, 17 individuals (30\%) were positive for only one virus, eight individuals (15\%) tested positive for two viruses, eight individuals (15\%) tested positive for 3 viru- ses, 11 individuals (20\%) tested positive for four viruses, and one animal (2\%) tested positive for 5 viruses (Fig. 3S).

\section{Variables Affecting Prevalence}

While there was model uncertainty in variables affecting probability of viral prevalence (Table 1; Table 1S), there was support for season as a main factor affecting probability of prevalence for FCoV, FCV, and FHV (Table 1; Table 1S). Likelihood ratio tests suggested that dropping sex from FCoV $(p=0.465)$ and FCV $(p=0.0515)$ improved model fit, which was confirmed with high overlap in confidence intervals between sexes in models which included sex and season affecting prevalence (Fig. 4S). 

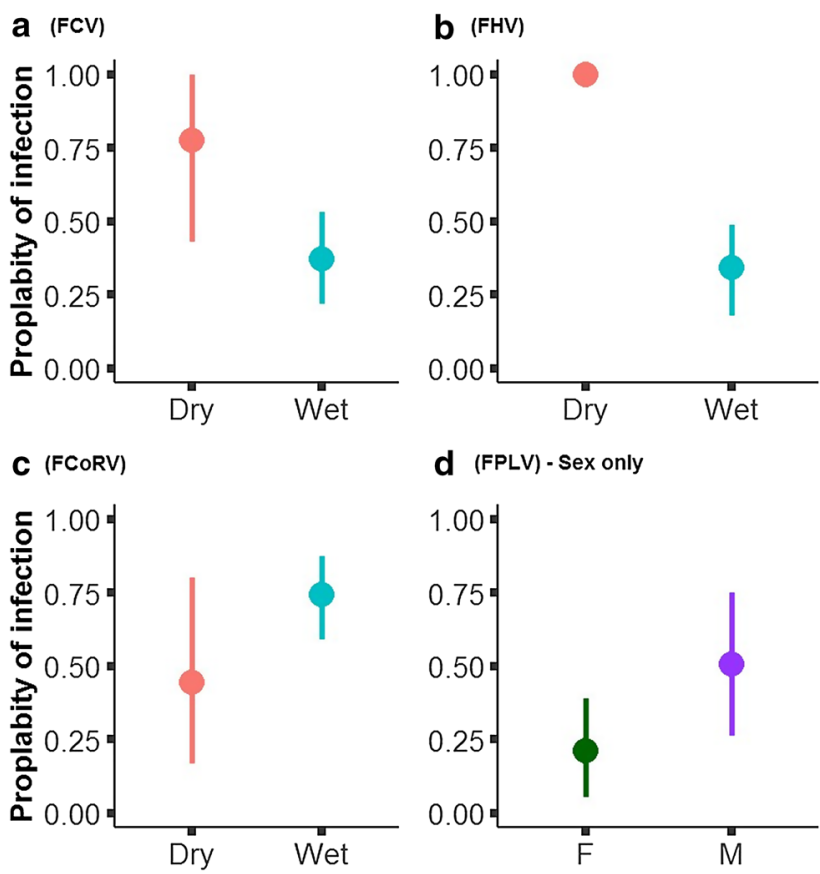

d (FPLV) - Sex only

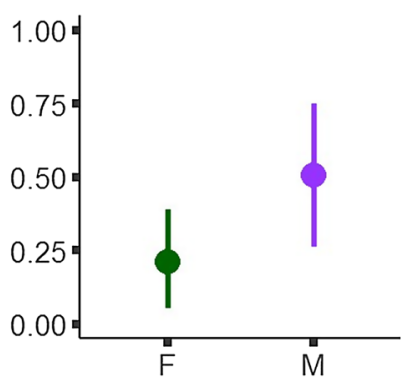

Figure 3. The probability of pathogen infection, influenced by season for a FCV, b FHV, c FCoV, and d FPLV affected by sex only.

Table 1. Summary of the Model Results and Ranking for the Various Variables Affecting the Different Pathogens Probability of Infection. Summary is Restricted to Models with $\triangle \mathrm{AICc}$ of $<2$, Full Model

\begin{tabular}{lllll}
\hline & AICc & Delta & ModelLik & ModelWt \\
\hline Disease -FCoV & & & & \\
FCoV $\sim$ season & 56.56 & 0 & 1 & 0.39 \\
FCoV sex + season & 58.34 & 1.77 & 0.41 & 0.16 \\
FCoV BCI & 58.38 & 1.82 & 0.4 & 0.16 \\
Disease -FPLV & & & & \\
FPLV sex & 53.83 & 0 & 1 & 0.33 \\
FPLV sex + season & 54.52 & 0.7 & 0.71 & 0.23 \\
FPLV season & 55.75 & 1.92 & 0.38 & 0.13 \\
Disease-FCV & & & & \\
FCV season & 58.54 & 0 & 1 & 0.31 \\
FCV $\sim$ season + sex & 59.54 & 1 & 0.61 & 0.19 \\
FCV sex & 59.89 & 1.35 & 0.51 & 0.16 \\
FCV $\sim$ sex + season & 60.47 & 1.94 & 0.38 & 0.12 \\
Disease-FHV & & & & \\
FHV $\sim$ season & 49.3 & 0 & 1 & 0.71 \\
\hline
\end{tabular}

Results Can be Seen in Table 1S.

Seroprevalence during the wet season was approximately half during the dry season for both FCV (wet season relative risk $=0.51$ ) and FHV (wet season relative risk $=0.34$;
Fig. 3). In contrast, for $\mathrm{FCoV}$, the prevalence was about double in the wet season compared to dry (wet season relative risk $=1.6$; Fig. 3). For FPLV, there was support for both sex and season affecting prevalence (Table 1; Table 1S); however, likelihood ratio tests suggested that dropping season improved model fit $(p=0.202)$, with further support from large overlap in 95\% confidence intervals for prevalence between seasons (Fig. 4S). As such, we retained only sex as a factor affecting FPLV prevalence where males had double the infection probability of females (male relative risk $=2.25$; Fig. 3 ). For most of the viruses tested, we did not find support for BCI affecting the prevalence except for $\mathrm{FCoV}$, where $\mathrm{BCI}$ seems to play a minor role (model weight of $<2 \Delta$ AICc $=0.16$; Table 1 ; Table 1S). Interestingly, the prevalence seems to increase with higher BCI scores (Fig. 5S).

\section{DIsCUSSION}

Approximately $82 \%$ of the servals screened over the course of the study tested positive for at least one of the five viruses included. This high prevalence, combined with large annual variation in serval population density (Loock et al. 2018), could suggest that viruses are probably an important factor in serval population dynamics at Secunda. Prevalence was high for most viruses, except for the retroviruses (FIV and FeLV). FIV prevalence could be underestimated because ELISA IDEXX ${ }^{\circledR}$ showed lower sensitivity for FIV belonging to wildcats of the Felis group (Brown et al. 2010). However, low FIV prevalence is common among wildcat, as we explain below. The prevalence of FCV, FCoV, FHV, and FPLV viruses was higher in our study than for most other wild African felids, except for some specific populations of lions in Tanzania and Uganda (Hoffman-Lehmann et al. 1996; Driciru et al. 2006), and caracals (Caracal caracal) in Namibia (Thalwitzer et al. 2010) although this study had a small sample size of 3 individuals. Virus prevalence often tends to be density dependent, so one possible explanation for this high prevalence in this study is the high density of this serval population $\left(76.2-101.1 \mathrm{serval} / 100 \mathrm{~km}^{2}\right.$ ) (Loock et al. 2018).

Retroviruses have low prevalence among the study population. This is similar to other African wild felid populations, where FIV has low prevalence, and there is no evidence of FeLV (Lutz et al. 1992; Kennedy et al. 2003; Ostrowski et al. 2003; Heddergott et al. 2018). The exceptions to this are lions with high prevalence of FIV (Hoff- 
man-Lehmann et al. 1996; Brown et al. 1993; Driciru et al. 2006; Ramsauer et al. 2007) and African wild cats (Felis silvestris lybica) with evidence of FeLV infection (Ostrowski et al. 2003). In contrast, for domestic cats FeLV is usually endemic (Oguzoglu et al. 2013; Muchaamba et al. 2014), which can lead to wild felid infections which are usually naive to the virus (Muchaamba et al. 2014). Continuous monitoring for FeLV remains important since the study area is surrounded by human settlements which are likely to have high numbers of domestic cats. Spillover of FeLV from domestic cats to serval remains a possibility, and FeLV transmission from domestic cats remains a serious threat for other wild cat species (Meli et al. 2010; Brown et al. 2018; Chiu et al. 2019). The spillover risk poses the possibility for closely related strains of pathogens to simultaneously be transmitted to other susceptible feline species (Kellner et al. 2018). Other external factors may also influence pathogen transmission such as seasonal variation affecting host susceptibility (for instance due to changing atmospheric conditions) (Dowell 2001), host behavior may change, and photoperiod-driven changes influencing physiological changes in mammalian species (Dowell 2001).

The strongest driver of viral infection in our analysis was season. There are no data available on the seasonal effects of viral infection prevalence among African felids, but in domestic cats in shelters, season influences the prevalence of FHV and FCV (Zicola et al. 2009; Meli et al. 2010). For FHV prevalence peaked in spring and autumn, and FCV infections peaked in winter and spring (Zicola et al. 2009; Meli et al. 2010), which may be related to the parturition period (Zicola et al. 2009; Meli et al. 2010). This is supported by (Goller et al. 2013) who demonstrated the importance of juvenile spotted hyenas (Crocuta crocuta) for the maintenance of coronavirus. For serval, the highest prevalence for FHV and FCV was in the dry season (winterspring), which corresponds with the pregnant-newborn season for serval (Smithers 1978). However, other seasonal variables should be considered, such as rainfall, temperature, and radiation, which directly affect the permanence of the virus in the environment. Times of increased physical contact between servals, for example, during mating season, could also play an important role.

Even though sex emerged as an important variable affecting pathogen infection, there was much uncertainly and overlap in infection probability between sexes. Sex was an important variable only for the prevalence of FPLV. This effect of sex on feline viral diseases has been explored for lion, cheetahs (Acinonyx jubatus), wildcat and sand cat (Felis margarita), although no clear relationship emerged (Hoffman-Lehmann et al. 1996; Ostrowski et al. 2003; Munson et al. 2004; Pomerantz et al. 2016). The only felid with clear effects of sex on pathogen infection was cheetah, where FHV was higher for males and FCV higher for females, although these results were not based on robust statistical analysis (Munson et al. 2004).

One factor that did not seem to be especially important in influencing the prevalence of most viruses was BCI. Nonetheless, body condition emerged as a driver for $\mathrm{FCoV}$, but in an unexpected manner, with animals with a higher BCI being more likely to test positive for antibodies to FCoV. A possible explanation for this is that animals with antibodies are those who survived a prior infection (possibly due in part to their better body condition) and develop a serological immune response against the virus. We did, however, find support for the hypothesis that BCI would be greater among adult males than adult female serval. This concurs with findings in other species, for example, two thirds of male Eurasian lynx (Lynx lynx) in Finland had greater BCI than females (Pulliainen et al. 1995). Coyotes (Canis latrans) in Texas, USA, with a high population density also showed a similar trend, with males having a 17\% higher BCI than females (Windberg et al. 1991). This is thought to be linked to the greater nutritional demands placed upon females due to their higher maternal physiological investment in reproduction and lactation (Windberg et al. 1991; Pulliainen et al. 1995).

Although season influenced disease prevalence, it did not appear to influence serval BCI. This contrasts with previous research that concluded that seasonal changes had a significant effect on body condition of Eurasian lynx (Pulliainen et al. 1995). This may be because seasonal changes at Secunda are less extreme than in Finland, and prey availability therefore varies to a much smaller extent between the seasons. A similar trend was also observed in coyotes in Texas, although interestingly fat deposits varied between seasons, but not overall body weight (Windberg et al. 1991). It is possible that although BCI did not change between seasons, more subtle metabolic changes such as these would have been missed.

FCoV had the highest prevalence in servals and is also common in caracal (Collier and O'Brien 1985; Thalwitzer et al. 2010). This is particularly important since FCoV has been reported as a source of mortality for servals in captivity (Juan-Sallés et al. 1998). Despite these threats, there are few data regarding coronavirus dynamics in wild pop- 
ulations. While season was shown as a key driver, it is unknown how seasonality might manifest in behaviors that affect infection risk.

\section{CONCLUSION}

The prevalence of antibodies to the most viruses for which we screened appeared to be high for servals at Secunda, although there are few other studies with which these prevalence can be compared. High viral infection prevalence may be linked to the high population density, season, and sex. We found little evidence that body condition played a large role in viral infection prevalence, and sex was the only factor that influenced body condition, with males in better physical condition than females. We therefore recommend continued viral surveillance of this population and suggest that long-term studies of changes in viral prevalence would be extremely useful to determine which factors influence felid epidemiology on a broader scale.

\section{ACKNOWLEDGEMENTS}

We would like to thank Secunda Synfuels Operations, Div. of Sasol South Africa Ltd., and the Centre for Sustainable Agriculture, Faculty of Natural and Agricultural Science, University of the Free State for supporting this research. We also want to acknowledge Dr G.E. Zeiler from the University of Pretoria and Dr M. Toft, Dr Schalk vd Merwe, and Dr Louw Grobler for conducting veterinary procedures. LHS was supported by the African Institute for Conservation Ecology, University of Venda and National Research Foundation (Grants UID 107099 \& 115040)

\section{DATA AVAILABILITY}

The datasets generated during and/or analyzed during the current study are available in the GitHub repository [h ttps://github.com/lourens-swanepoel/Serval_health].

\section{Declarations}

ETHICAL APPROVAL All applicable institutional and/ or national guidelines for the care and use of animals were followed. This project was approved by the Animal Use and Care Committee of the University of Pretoria South Africa
(Ethical clearance number: EC040-14, V044-17) and the Mpumalanga Tourism and Parks Agency (Permit number: $5467 \& 7282)$.

\section{OPEN Access}

This article is licensed under a Creative Commons Attribution 4.0 International License, which permits use, sharing, adaptation, distribution and reproduction in any medium or format, as long as you give appropriate credit to the original author(s) and the source, provide a link to the Creative Commons licence, and indicate if changes were made. The images or other third party material in this article are included in the article's Creative Commons licence, unless indicated otherwise in a credit line to the material. If material is not included in the article's Creative Commons licence and your intended use is not permitted by statutory regulation or exceeds the permitted use, you will need to obtain permission directly from the copyright holder. To view a copy of this licence, visit http://creativec ommons.org/licenses/by/4.0/.

\section{REFERENCES}

Akaike H (1974) A new look at the statistical model identification. IEEE Transactions on Automatic Control 19(6):716-723. https:// doi.org/10.1109/TAC.1974.1100705

Bradley CA, Altizer S (2007) Urbanization and the ecology of wildlife diseases. Trends in Ecology \& Evolution 22(2):95-102. https://doi.org/10.1016/j.tree.2006.11.001

Brown, E. W., Miththapala, S., \& O’Brien, S. J. (1993). Prevalence of exposure to feline immunodeficiency virus in exotic felid species. Journal of Zoo and Wildlife Medicine,, 357-364. https:// www.jstor.org/stable/20095289.

Brown MA, Cunningham MJ, Roca AL, Troyer JL, Johnson WE, O'Brien SJ (2018) Genetic characterization of feline leukemia virus from Florida panthers. Emerging Infectious Diseases. 14(2):252-259. https://doi.org/10.3201/eid1402.070981

Brown MA, Munkhtsog B, Troyer JL, Ross S, Seller R, Fine AE, O'Brien SJ (2010) Feline immunodeficiency virus (FIV) in wild Pallas' cats. Veterinary Immunology and Immunopathology. https://doi.org/10.1016/j.vetimm.2009.10.014

Burnham, K. P., \& Anderson, D. R. (2002). A practical information-theoretic approach. Model selection and multimodel inference. Springer.

Chakraborty C, Sharma AR, Sharma G, Bhattacharya M, Lee SS (2020) SARS-CoV-2 causing pneumonia-associated respiratory disorder (COVID-19): diagnostic and proposed therapeutic options. Eur Rev Med Pharmacol Sci 24(7):4016-4026

Chiu ES, Kraberger S, Cunningham M, Cusack L, Roelke M, VandeWoude S (2019) Multiple introductions of domestic cat feline leukemia virus in endangered florida panthers. Emerging 
Infectious Diseases 25(1):92-101. https://doi.org/10.3201/ eid2501.181347

Collier GE, O'Brien SJ (1985) A molecular phylogeny of the Felidae: immunological distance. Evolution 39(3):473-487. https:// doi.org/10.1111/j.1558-5646.1985.tb00389.x

Cumming G (2009) Inference by eye: reading the overlap of independent confidence intervals. Statistics in Medicine 28(2):205-220. https://doi.org/10.1002/sim.3471

De Soto, J., Hakim, S., \& Boyd, F. (2020). The Pathophysiology of virulence of the COVID-19 virus. Preprints, https://doi.org/10. 20944/preprints202004.0077.v2

Devleesschauwer, B., Torgerson, P., Charlier, J., Levecke, B., Praet, N., Roelandt , S., Speybroeck, N. (2014). Prevalence: tools for prevalence assessment studies. $R$ package version, 3(0). http://cra n.r-project.org/package $=$ prevalence.

Donoghoe, M. W., \& Marschner, I. C. (2018). logbin: An R package for relative risk regression using the log-binomial model. . J Stat Softw, 86(1), 1-22. https://doi.org/10.18637/jss. v086.i09.

Dowell SF (2001) Seasonal variation in host susceptibility and cycles of certain infectious diseases. Emerging Infectious Diseases 7(3):369. https://doi.org/10.3201/eid0703.017301

Driciru M, Siefert L, Prager KC, Dubovi E, Sande R, Princee F, Munson L (2006) A serosurvey of viral infections in lions (Panthera leo), from Queen Elizabeth National Park, Uganda. Journal of Wildlife Diseases 42(3):667-671. https://doi.org/ 10.7589/0090-3558-42.3.667

Emslie, K. W. (2018). Industrial landscapes promote small carnivore diversity and modulate the predation experienced by small mammals. University of Venda. http://hdl.handle.net/11602/11 22: Department of Zoology, School of Mathematics and Natural Science.

Ferreira SM, Funston PJ (2010) Estimating lion population variables: prey and disease effects in Kruger National Park, South Africa. Wildlife Research 37(3):194-206. https://doi.org/10.1071/ WR09030

Franklin SP, Kays RW, Moreno R, TerWee JA, Troyer JL, VandeWoude S (2008) Ocelots on Barro Colorado Island are infected with feline immunodeficiency virus but not other common feline and canine viruses. Journal of Wildlife Diseases 44(3):760-765. https://doi.org/10.7589/0090-3558-44.3.760

Fromont E, Sager A, Leger F, Bourguemestre F, Jouquelet E, Stahl R, Artos M (2000) Prevalence and pathogenicity of retroviruses in wildcats in France. Veterinary Record 146(11):317-319. https://doi.org/10.1136/vr.146.11.317

Goller KV, Fickel J, Hofer H, Beier S, East ML (2013) Coronavirus genotype diversity and prevalence of infection in wild carnivores in the Serengeti National Park, Tanzania. Archives of Virology 158(4):729-734. https://doi.org/10.1007/s00705-012-1562-x

Green AJ (2001) Mass/length residuals: measures of body condition or generators of spurious results? Ecology 82(5):1473-1483. https:// doi.org/10.1890/0012-9658(2001)082[1473:MLRMOB]2.0.CO;2

Heddergott, M., Steeb, S., Osten-Sacken, N., Steinbach, P., Schneider, S., Pir, J. P., Frantz, A. C. (2018). Serological survey of feline viral pathogens in free-living European wildcats (Felis s. silvestris) from Luxembourg. Archives of Virology,, 163(11), 3131-3134. https://doi.org/10.1007/s00705-018-3972-x.

Hoffman-Lehmann, R., Fehr, D., Grob, M., Elgizoli, M., Packer, G., Martenson, J. S., Lutz, H. (1996). Prevalence of antibodies to feline parvovirus, calicivirus, herpesvirus, coronavirus, and immunodeficiency virus and of feline leukemia virus antigen and the interrelationship of these viral infections in free-ranging lions in east Africa. Clinical and Diagnostic Laboratory Immunology,, 3(5), 554-562. http://cvi.asm.org/content/3/5/554. short.

Jakob EM, Marshall SD, Uetz GW (1996) Estimating fitness: a comparison of body condition indices. Oikos. https://doi.org/ $10.2307 / 3545585$

Juan-Sallés C, Domingo M, Herráez P, Fernández A, Segalés J, Fernández J (1998) Feline infectious peritonitis in servals (Felis serval). Veterinary Record 143:535-535. https://doi.org/10.1136/ vr.143.19.535

Kellner A, Carver S, Scorza V, McKee CD, Lappin M, Crooks KR, Antolin MF (2018) Transmission pathways and spillover of an erythrocytic bacterial pathogen from domestic cats to wild felids. Ecology and Evolution 8(19):9779-9792. https://doi.org/ 10.1002/ece 3.4451

Kennedy M, Kania S, Stylianides E, Bertschinger H, Keet D, van Vuuren M (2003) Detection of feline coronavirus infection in southern African nondomestic felids. Journal of Wildlife Diseases 39(3):529-535. https://doi.org/10.7589/0090-3558-39.3.529

Labocha MK, Schutz H, Hayes JP (2014) Which body condition index is best? Oikos 123(1):111-119. https://doi.org/10.1111/ j.1600-0706.2013.00755.x

Lindenfors P, Nunn CL, Jones KE, Cunningham AA, Sechrest W, Gittleman JL (2007) Parasite species richness in carnivores: effects of host body mass, latitude, geographical range and population density. Global Ecology and Biogeography 16(4):496-509. https://doi.org/10.1111/j.1466-8238.2006.00301.x

Loock DJ, Williams ST, Emslie KW, Matthews WS, Swanepoel LH (2018) High carnivore population density highlights the conservation value of industrialised sites. Scientific Reports 8(1):1-9. https://doi.org/10.1038/s41598-018-34936-0

Luo J, Zhang J, Sun H (2014) Estimation of relative risk using a log-binomial model with constraints. Computational Statistics 29(5):981-1003. https://doi.org/10.1007/s00180-013-0476-8

Lutz H, Isenbügel E, Lehmann R, Sabapara R, Wolfensberger R (1992) Retrovirus infections in non-domestic felids: serological studies and attempts to isolate a lentivirus. Veterinary Immunology and Immunopathology 35(1-2):215-224. https:// doi.org/10.1016/0165-2427(92)90133-B

Martínez-Hernandez F, Isaak-Delgado AB, Alfonso-Toledo JA, Munoz-Garcia CI, Villalobos G, Arechiga-Ceballos N, RendonFranco E (2020) Assessing the SARS-CoV-2 threat to wildlife: potential risk to a broad range of mammals. Perspectives in Ecology and Conservation . https://doi.org/10.1016/j.pecon.2020.09.008

Matooane M, Oosthuizen R, John J (2011) Self-reported hypertension in eMbalenhle, Mpumalanga, South Africa: findings from a vulnerability to air pollution assessment. Southern African Journal of Epidemiology and Infection 26(4):280-284. https://doi.org/10.1080/10158782.2011.11441468

Meli ML, Cattori V, Martínez F, López G, Vargas A, Palomares F, Lutz H (2010) Feline leukemia virus infection: a threat for the survival of the critically endangered Iberian lynx (Lynx pardinus). Veterinary Immunology and Immunopathology 134(12):61-67. https://doi.org/10.1016/j.vetimm.2009.10.010

Meli ML, Cattori V, Martinez F, Lopez G, Vargas A, Simon MA, Lutz H (2009) Feline leukemia virus and other pathogens as important threats to the survival of the critically endangered iberian lynx (Lynx pardinus). PLoS One 4(3):e4744. https:// doi.org/10.1371/journal.pone.0004744 
Meyer B, Drosten C, Müller MA (2014) Serological assays for emerging coronaviruses: challenges and pitfalls. Virus Research 194:175-183. https://doi.org/10.1016/j.virusres.2014.03.018

Morris PJ (2001) Chemical immobilization of felids, ursids, and small ungulates. Veterinary Clinics of North America: Exotic Animal Practice 4(1):267-298. https://doi.org/10.1016/S10949194(17)30060-9

Muchaamba F, Mutiringindi TH, Tivapasi MT, Dhliwayo S, Matope G (2014) A survey of feline leukaemia virus infection of domestic cats from selected areas in Harare, Zimbabwe. Journal of the South African Veterinary Association 85(1):01. https:// doi.org/10.4102/jsava.v85i1.1126

Munson L, Marker L, Dubovi E, Spencer JA, Evermann JF, O'Brien SJ (2004) Serosurvey of viral infections in free-ranging Namibian cheetahs (Acinonyx jubatus). Journal of Wildlife Diseases 40(1):23-31. https://doi.org/10.7589/0090-3558-40.1.23

Munson L, Terio KA, Ryser-Degiorgis MP, Lane EP, Courchamp F (2010) Wild felid diseases: conservation implications and management strategies. Biology and Conservation of Wild Felids 237:259

Naidenko SV, Pavlova EV, Kirilyuk VE (2014) detection of seasonal weight loss and a serologic survey of potential pathogens in wild pallas'cats (felis [otocolobus] manul) of the Daurian steppe, Russia. Journal of Wildlife Diseases 50(2):1. https:// doi.org/10.7589/2013-03-068

Oguzoglu TC, Muz D, Timurkan MO, Maral N, Gurcan IS (2013) Prevalences of feline coronavirus (FCoV), feline leukaemia virus (FeLV), feline immunodeficiency virus (FIV) and feline parvovirus (FPV) among domestic cats in Ankara, Turkey. Revue Méd Vét 164(11):511-516

Ostrowski S, Van Vuuren M, Lenain DM, Durand A (2003) A serologic survey of wild felids from central west Saudi Arabia. Journal of Wildlife Diseases 39(3):696-701. https://doi.org/ 10.7589/0090-3558-39.3.696

Ou X, Liu Y, Lei X, Li P, Mi D, Ren L, Qian Z (2020) Characterization of spike glycoprotein of SARS-CoV-2 on virus entry and its immune cross-reactivity with SARS-CoV. Nature Communications 11(1):1-12. https://doi.org/10.1038/s41467-02015562-9

Pedersen AB, Jones KE, Nunn CL, Altizer S (2007) Infectious disease and mammalian extinction risk. Conservation Biology 21:1269-1279. https://doi.org/10.1111/j.1523-1739.2007.00776.x

Pedersen NC (2009) A review of feline enteric coronavirus infection. Journal Feline Med Surg 11:225-258. https://doi.org/ 10.1016/j.jfms.2008.09.008

Pinheiro, J., Bates, D., DebRoy, S., \& Sarkar, D. (2019). R Core Team. 2019. nlme: linear and nonlinear mixed effects models. $R$ package version 3.1-141., Available at h Ttp://CRAN. R-Project. Org/Package $=$ Nlme.

Pomerantz J, Rasambainarivo FT, Dollar L, Rahajanirina LP, Andrianaivoarivelo R, Parker P, Dubovi E (2016) Prevalence of antibodies to selected viruses and parasites in introduced and endemic carnivores in western Madagascar. Journal of Wildife Diseases 52(3):544-552. https://doi.org/10.7589/2015-03-063

Pulliainen E, Lindgren E, Tunkkari PS (1995) Influence of food availability and reproductive status on the diet and body condition of the European lynx in Finland. Acta Theriologica 40:181-181

Ramsauer, S., Bay, G., Meli, M., Hofmann-Lehmann, R., \& Lutz, H. (2007). Seroprevalence of selected infectious agents in a freeranging, low-density lion population in the Central Kalahari Game Reserves in Botswana. Clinical and Vaccine Immunology,, 14(6), https://doi.org/10.1128/CVI.00307-06.

Renwick AR, White PC, Bengis RG (2007) Bovine tuberculosis in southern African wildlife: a multi-species host-pathogen system. Epidemiology \& Infection 135(4):529-540. https://doi.org/ 10.1017/S0950268806007205

Schulte-Hostedde AI, Zinner B, Millar JS, Hickling GJ (2005) Restitution of mass-size residuals: validating body condition indices. Ecology 86(1):155-163. https://doi.org/10.1890/04-0232

Shi J, Wen Z, Zhong G, Yang H, Wang C, Huang B, Bu Z (2020) Susceptibility of ferrets, cats, dogs, and other domesticated animals to SARS-coronavirus 2. Science 368(6494):1016-1020. https://doi.org/10.1126/science.abb7015

Smith KF, Acevedo-Whitehouse K, Pedersen AB (2009) The role of infectious diseases in biological conservation. Animal Conservation 12(1):1-12. https://doi.org/10.1111/j.1469-1795.2008.00228.x

Smithers RH (1978) The serval Felis serval Schreber, 1776. South African Journal of Wildlife Research-24-Month Delayed Open Access 8(1):29-37

Stoddart CA, Scott FW (1989) Intrinsic resistance of feline peritoneal macrophages to coronavirus infection correlates with in vivo virulence. Journal of Virology 63(1):436-440

Team, R. C. (2015). R: A language and environment for statistical computing. http://www.R-project.org/.

Thalwitzer S, Wachter B, Robert N, Wibbelt G, Muller T, Lonzer J, Lutz $H$ (2010) Seroprevalences to viral pathogens in freeranging and captive cheetahs (Acinonyx jubatus) on Namibian farmland. Clinical and Vaccine Immunology 17(2):2. https:// doi.org/10.1128/CVI.00345-09

Wickham H (2009) Ggplot 2: Introduction; 2 Getting started with qplot; 3 Mastering the grammar; 4 Build a plot layer by layer; 5 Toolbox; 6 Scales, axes and legends; 7 Positioning; 8 Polishing your plots for publication; 9 Manipulating data; 10 Reducing duplication. Springer. https://doi.org/10.1007/978-0-387-981413_2

Windberg LA, Engeman RM, Bromaghin JF (1991) Body size and condition of coyotes in southern Texas. Journal of Wildlife Diseases 27(1):47-52. https://doi.org/10.7589/0090-3558-27.1.47

Zicola A, Saegerman C, Quatpers D, Viandier J, Thiry E (2009) Feline herpesvirus 1 and feline calicivirus infections in a heterogeneous cat population of a rescue shelter. Journal of Feline Medicine and Surgery 11(12):1023-1027. https://doi.org/ 10.1016/j.jfms.2009.05.023 